\title{
Trends in suicide in Scotland 1974-84: an increasing problem
}

\author{
P MCLOONE, I K CROMBIE
}

\begin{abstract}
A detailed investigation of trends in suicide rates in Scotland from 1974 to 1984 showed a complex pattern. Overall rates for men increased by $40 \%$ with the greatest increases in those aged 45-64. In contrast, rates for women showed a small decline, which was most noticeable in those aged 15-24. The well recognised decline in poisoning by domestic gas was seen over this period, and suicide by this method virtually stopped. Both sexes showed a decline in suicide by poisoning with drugs, although the decrease was larger among women. The fall in suicide rates among young women was almost all due to the decrease in this method. The rise in rates for men was largely due to increases in hanging and poisoning with vehicle exhaust gases, although all methods except drugs and domestic gas showed some increase.
\end{abstract}

These findings indicate that suicide is an increasing problem with causes that are far from understood, so that prevention may be difficult.

\section{Introduction}

Suicide rates in Britain fell appreciably between 1963 and 1971 owing to a decline in suicide by poisoning by domestic gas. ${ }^{12}$ This is attributed to the fall in the carbon monoxide content of domestic gas when coal gas was replaced by natural gas. One feature of this fall was the absence of a compensatory shift to other methods of suicide. ${ }^{2}$ In fact, in over 100 years suicide by domestic gas poisoning and poisoning by solid or liquid substances varied independently of all other methods. ${ }^{3}$

Cardiovascular Epidemiology Unit, Ninewells Hospital and Medical School, Dundee DD1 9SY

P MCLOONE, BSC, statistician

I K CROMBIE, BSC, PHD, senior statistician

Correspondence to: $\mathrm{Mr}$ McLoone.
Suicide rates in the early 1970 s remained constant, ${ }^{14}$ but a rise was reported for the rest of the decade in England and Wales. ${ }^{56}$ This overall increase, however, concealed differing trends for the varying methods. Thus despite the concern expressed about self poisoning with drugs $\mathrm{s}^{7}$ there was a reduction in suicide by this method. ${ }^{56}$ The overall rise in England and Wales has occurred in suicides by poisoning by vehicle exhaust gas, hanging, strangulation, and suffocation.

To determine what trends have occurred in Scotland and to extend the analysis to more recent years we studied reported suicides from 1974 to 1984.

\section{Methods}

Details of all deaths in Scotland over the period 1974-84 were received on magnetic tape from the registrar general of Scotland. Deaths from suicide (International Classification of Diseases E950-959) and injury that was undetermined (E980-989), whether accidentally or purposely inflicted, were extracted and analysed by a specially developed computerised system. Extensive cross checking against the reports of the registrar general showed that the computerised system produced data identical with that published but provided greater detail. Death rates were expressed per 100000 population and calculated for all ages $\geqslant 15$ and for the age groups 15-24, $25-44,45-64$, and $\geqslant 65$ for both sexes and each method of suicide. These data embrace two revisions of the International Classification of Diseases (the Eighth and Ninth), but a double coding exercise by the registrar general showed that the coding of suicide was unaffected by the revision. ${ }^{8}$

\section{Results}

OVERALI TRENDS AND INDIVIDUAL METHODS 1974-8

The number of deaths from suicide among men aged 15 and over was 259 in 1974 and rose to 359 in 1984; for women there was a slight fall from 177 to 157. An examination of the trend in suicide rate showed that the rates for men increased steadily from the mid-1970s with the rate of increase slowing in later years (figure). In contrast, rates for women, which were initially lower, showed a slight decrease over this period and by 1984 were less than half the rates for men.

There were also noticeable differences betwen men and women in the method of suicide used (table I). When the rates over the period 1974-84 were combined it was clear that hanging and strangulation were the most commonly used methods among men; poisoning by solids or liquids was 


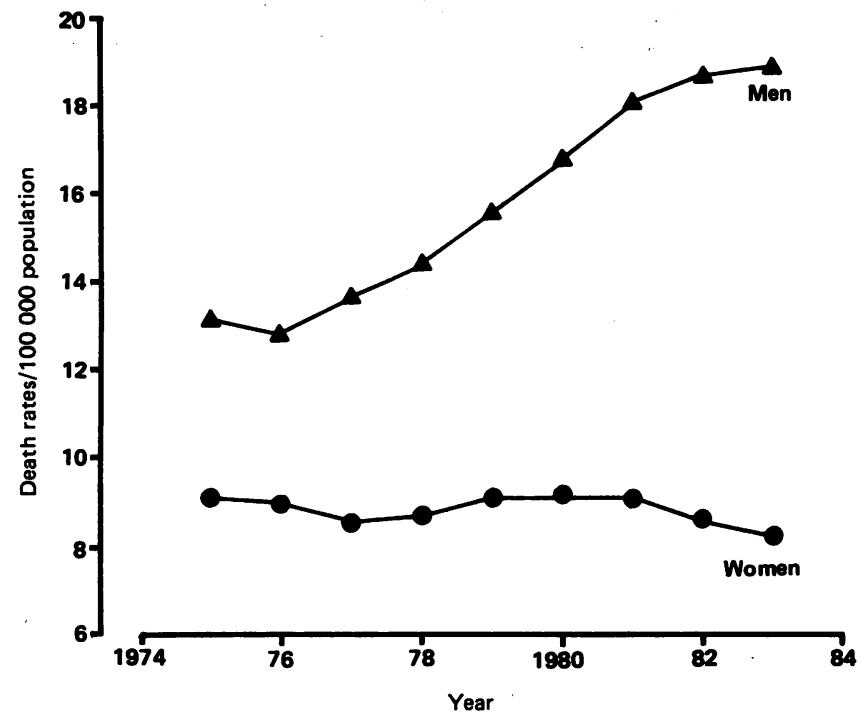

Trends in mortality from suicide among men and women aged 15 and over during 1974-84; data plotted as three point moving averages.

slightly less common. Among women poisoning by solids or liquids was by far the most common method, with a rate $(4 \cdot 8 / 100000)$ exceeding that for men $(4 \cdot 1 / 100000)$. Drowning was the next most common method for women; the rate was similar to that for men. For all other methods of suicide the rates for women were considerably below those for men; the difference was most noticeable for hanging, strangulation, and firearms. Suicide by poisoning by domestic gas was very uncommon for both sexes.

The introduction of the ninth revision of the International Classification of Diseases in 1979 provided finer subdivisions of the methods of suicide, and these were investigated over the period 1979-84. Among men $94 \%$ of the category hanging and strangulation (E953) was due to hanging alone; for women the figure was $70 \%$. Medical compounds (drugs) accounted for $87 \%$ of poisonings by solids and liquids (E950) among men and $95 \%$ among women. In all except one of the cases of poisoning by domestic gas (E951) liquid petroleum gas distributed in mobile containers was used. Motor vehicle exhaust accounted for almost all cases of non-domestic gas poisoning (E952) ( $92 \%$ of the men and $86 \%$ of the women). For clarity we have used the terms hanging, drugs, and vehicle exhaust in place of the longer versions.

\section{TRENDS WITHIN METHODS AND AGE GROUPS}

An examination of the trends by method among men showed that the increase in the overall rate was the net effect of quite different trends in the individual methods of suicide (table II). The greatest rises occurred for poisoning by motor vehicle exhaust and hanging. Poisoning by drugs showed a small fall and as a result was replaced by hanging as the most common method. The predominant change among women was the fall in the rate of poisoning by drugs, although this still remained the most common method. The other methods showed only small changes, but of these the largest was the increase in hanging.

The trends in suicide rates also varied to different extents among the different age groups. In 1974-6 the suicide rate among men showed an increase with age to a maximum for age $\geqslant 65$ (table III). The rates for each age group of men increased subsequently but with the greatest absolute rises

TABLE I-Mortality (per 100000 population) by method of suicide for men and women aged 15 and over, 1974-84. (Numbers in parentheses are total numbers of deaths)

\begin{tabular}{lll}
\hline Cause of death & \multicolumn{1}{c}{ Men } & Women \\
\hline Hanging and strangulation & $4.55(932)$ & $1.01(230)$ \\
Poisoning by solids and liquids & $4.12(844)$ & $4.85(1105)$ \\
Poisoning by non-domestic gas & $1.84(376)$ & $0.17(38)$ \\
Drowning & $1 \cdot 77(363)$ & $1.61(367)$ \\
Firearms & $1.26(259)$ & $0.09(23)$ \\
Unspecified & $0.99(204)$ & $0.30(68)$ \\
Jumping & $0.90(185)$ & $0.55(125)$ \\
Cutting and stabbing & $0.33(68)$ & $0.09(20)$ \\
Poisoning by domestic gas & $0.17(34)$ & $0.05(11)$ \\
\hline
\end{tabular}

occurring in the $45-64$ and $25-44$ groups. Thus by $1982-4$ the rate was highest for the age group 45-64. In contrast, for women there was a noticeable (52\%) fall in the rate at ages 15-24 but little change in the other age groups.

Trends in suicide were examined by method within age group (data not shown). The rapid rise in suicide in men in the age groups 25-44 and 45-64 occurred, as would be expected, mainly in suicide by hanging and by poisoning by vehicle exhaust gas. The fall in suicide in women that occurred in the age group 15-24 was nearly all attributed to a reduction in poisoning by drugs (a reduction of $63 \%$, considerably greater than that in the other age groups).

\begin{tabular}{|c|c|c|c|c|}
\hline Cause of death & Sex & $1974-6$ & $1982-4$ & Difference* \\
\hline $\begin{array}{l}\text { Poisoning by solid or } \\
\text { liquid substances (E950) }\end{array}$ & $\left\{\begin{array}{l}\text { Men } \\
\text { Women }\end{array}\right.$ & $\begin{array}{l}4 \cdot 16(230) \\
5 \cdot 57(344)\end{array}$ & $\begin{array}{l}3.93(221) \\
3.87(243)\end{array}$ & $\begin{array}{l}-0 \cdot 23 \\
-1 \cdot 70\end{array}$ \\
\hline $\begin{array}{l}\text { Poisoning by gases in } \\
\text { domestic use (E951) }\end{array}$ & $\left\{\begin{array}{l}\text { Men } \\
\text { Women }\end{array}\right.$ & $\begin{array}{l}0 \cdot 45(25) \\
0 \cdot 18(11)\end{array}$ & $\begin{array}{l}0.07(4) \\
0.00\end{array}$ & $\begin{array}{l}-0.38 \\
-0.18\end{array}$ \\
\hline $\begin{array}{l}\text { Poisoning by other } \\
\text { gases or vapours (E952) }\end{array}$ & $\left\{\begin{array}{l}\text { Men } \\
\text { Women }\end{array}\right.$ & $\begin{array}{l}0 \cdot 83(46) \\
0 \cdot 12(7)\end{array}$ & $\begin{array}{l}2 \cdot 81(158) \\
0 \cdot 25(16)\end{array}$ & $\begin{array}{l}1.98 \\
0.13\end{array}$ \\
\hline $\begin{array}{l}\text { Hanging, strangulation, } \\
\text { and suffocation (E953) }\end{array}$ & $\left\{\begin{array}{l}\text { Men } \\
\text { Women }\end{array}\right.$ & $\begin{array}{l}3.36(189) \\
0.84(52)\end{array}$ & $\begin{array}{l}5 \cdot 72(323) \\
1 \cdot 23(77)\end{array}$ & $\begin{array}{l}2 \cdot 36 \\
0 \cdot 39\end{array}$ \\
\hline $\begin{array}{l}\text { Submersion (drowning) } \\
\text { (E954) }\end{array}$ & $\left\{\begin{array}{l}\text { Men } \\
\text { Women }\end{array}\right.$ & $\begin{array}{l}1 \cdot 71(94) \\
1 \cdot 56(96)\end{array}$ & $\begin{array}{l}1 \cdot 77(100) \\
1 \cdot 71(107)\end{array}$ & $\begin{array}{l}0.06 \\
0.15\end{array}$ \\
\hline $\begin{array}{l}\text { Injury by firearms } \\
\text { and explosives (E955) }\end{array}$ & $\left\{\begin{array}{l}\text { Men } \\
\text { Women }\end{array}\right.$ & $\begin{array}{l}0.91(50) \\
0.05(3)\end{array}$ & $\begin{array}{l}1 \cdot 82(102) \\
0 \cdot 18(12)\end{array}$ & $\begin{array}{l}0.91 \\
0.13\end{array}$ \\
\hline $\begin{array}{l}\text { Injury by cutting and } \\
\text { piercing instruments (E956) }\end{array}$ & $\left\{\begin{array}{l}\text { Men } \\
\text { Women }\end{array}\right.$ & $\begin{array}{l}0.33(18) \\
0.05(3)\end{array}$ & $\begin{array}{l}0.34(19) \\
0.06(4)\end{array}$ & $\begin{array}{l}0.01 \\
0.01\end{array}$ \\
\hline $\begin{array}{l}\text { Jumping from high } \\
\text { places (E957) }\end{array}$ & $\left\{\begin{array}{l}\text { Men } \\
\text { Women }\end{array}\right.$ & $\begin{array}{l}0.67(37) \\
0.47(29)\end{array}$ & $\begin{array}{l}1 \cdot 25(70) \\
0.63(40)\end{array}$ & $\begin{array}{l}0.58 \\
0.16\end{array}$ \\
\hline $\begin{array}{l}\text { Other and unspecified } \\
\text { means (E958) }\end{array}$ & $\left\{\begin{array}{l}\text { Men } \\
\text { Women }\end{array}\right.$ & $\begin{array}{l}0 \cdot 82(45) \\
0 \cdot 26(16)\end{array}$ & $\begin{array}{l}1 \cdot 28(73) \\
0 \cdot 27(17)\end{array}$ & $\begin{array}{l}0.46 \\
0.01\end{array}$ \\
\hline
\end{tabular}

^ Rate for 1982-4 minus rate for 1974-6.

TABLE III-Mortality (per 100000 population) from suicide according to sex and age group in 1974-6 and 1982-4. (Numbers in parentheses are total numbers of deaths)

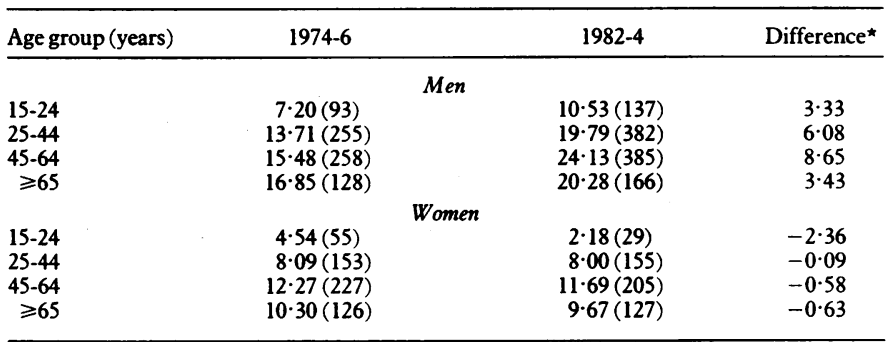

^ Rate for 1982-4 minus rate for 1974-6.

\section{POSSIBLE SOURCE OF CONFOUNDING}

Some part of these trends might have been due to changes in the category "deaths undetermined whether accidentally or purposely inflicted" (E980-989). Thus the trends in this category were examined to determine whether changes in the official suicide rates could be explained by a transfer of deaths to or from this "undetermined" group (table IV). For both sexes there was a decrease in the number of deaths assigned to this category during 1974-84. Most of these deaths (about $80 \%$ ) occurred in the two categories poisoning by solid or liquid substances and drowning. For both sexes poisoning by solids or liquids fell and there was also a slight decrease in the rates of drowning. The other methods of death in the undetermined group constituted only a small proportion of all such deaths but they showed a small rise among men and a fall among women. Overall transfers of deaths between this category and that of suicide could not explain the observed trends in the latter.

\section{Discussion}

This study found appreciable trends in suicide rates. Rates for men increased by over $40 \%$ in 10 years while rates for women showed a small decrease over the same period. Thus in contrast to 
the 1960s, when rates for both sexes fell because of the decrease in the use of toxic domestic coal gas, ${ }^{12}$ the more recent pattern has been for the trends in men and women to be independent. The implication of this is that some change in society or the physical environment has occurred that has principally affected men.

There has been considerable interest in the association between unemployment and suicide, and this was reviewed by Platt. ${ }^{9}$ To explain the recent trends in suicide the increase in unemployment must have been more strongly experienced by men, and there is some support for this in the fact that the greatest increase in suicide

TABLE IV-Comparison of mortality (per 100000 population) in 1974-6 and 1982-4 from "deaths undetermined whether accidentally or purposely inflicted" (E980-989) among men and women aged 15 and over. (Numbers in parentheses are total numbers of deaths)

\begin{tabular}{|c|c|c|c|c|}
\hline Cause of death & Sex & $1974-6^{\star}$ & $1982-4^{\star}$ & Difference \\
\hline $\begin{array}{l}\text { Poisoning by solid or } \\
\text { liquid substances (E980) }\end{array}$ & $\left\{\begin{array}{l}\text { Men } \\
\text { Women }\end{array}\right.$ & $\begin{array}{l}3 \cdot 18(176) \\
3 \cdot 45(212)\end{array}$ & $\begin{array}{l}1 \cdot 64(92) \\
1.68(105)\end{array}$ & $\begin{array}{l}-1.54 \\
-1.77\end{array}$ \\
\hline Drowning (E984) & $\left\{\begin{array}{l}\text { Men } \\
\text { Women }\end{array}\right.$ & $\begin{array}{l}2 \cdot 43(139) \\
0.65(41)\end{array}$ & $\begin{array}{l}2 \cdot 12(120) \\
0 \cdot 59(38)\end{array}$ & $\begin{array}{l}-0.31 \\
-0.06\end{array}$ \\
\hline Remainder of E980-989 & $\left\{\begin{array}{l}\text { Men } \\
\text { Women }\end{array}\right.$ & $\begin{array}{l}1.35(80) \\
0.65(44)\end{array}$ & $\begin{array}{l}2 \cdot 02(115) \\
0.52(34)\end{array}$ & $\begin{array}{r}0.67 \\
-0.13\end{array}$ \\
\hline
\end{tabular}

* Average over the three year period. † Rate for 1982-4 minus rate for 1974-6.

was among men of working age (25-64 years). The relation between suicide and unemployment, however, may be far from simple, with an interplay of the effect of mental health on the chances of being unemployed and the effect of unemployment on mental health. ${ }^{9} 10$

An association exists between alcoholism and suicide, and the potential importance of this in Scotland has been discussed. ${ }^{112}$ To account for the trends in suicide reported here there would have to have been a considerable rise in alcoholism in Scotland. Although the liquor licensing laws in Scotland were changed in 1976, a recent assessment showed that the change in the law saw no appreciable effect on morbidity and mortality related to alcohol.$^{13}$ It thus seems unlikely that these changes had a major effect on suicide rates.

The complexity of the causes of suicide is emphasised by the fact that the overall changes in the Scottish rates conceal complex patterns when the individual methods are examined. Both sexes showed a fall in the frequency of suicide by poisoning with solid or liquid substances (drugs). Among women this fall overwhelmed the small rise in suicide by other methods. Among men, however, the decline in suicide by drugs was overwhelmed by large rises in the frequency of other methods.

One possible explanation for the fall in suicide by drugs could be a reduction in availability: it has been suggested that the replacement of barbiturates by the less toxic benzodiazepines has played an important part. ${ }^{14}$ is An alternative explanation is that the trends in the number of prescriptions for hypnotics and tranquillisers are the important factor. ${ }^{16}$ There may, however, be factors other than availability of drugs that are responsible as this study found that the fall was considerably greater among women aged 15-24 than other groups. It seems unlikely that availability was reduced to so much larger an extent in this group than in all the others.

Among men rates of suicide from poisoning by vehicle exhaust and from hanging showed a rapid rise, and although rates among women also increased they were one tenth of the rates for men. It might be speculated that the sex difference for poisoning by vehicle exhaust reflects differences in either availability of or attitude towards cars. Part of the increase in use of this method could be due to increased car ownership, but other factors may be responsible. Bulusu and Alderson found that suicide by poisoning from car exhaust in England and Wales had risen faster than car registrations and suggested that the rise may reflect a snowball effect of people discovering it as an available method. ${ }^{6}$ If true, suicide by this method could play the part previously taken by domestic gas as awareness of the method spreads. This must raise a serious ethical question about the publicity that is given to this method. The increase in suicide by hanging cannot easily be explained by changing availability or a snowball effect. It is of concern that for both hanging and poisoning by car exhaust little can be done to limit availability. In contrast with prescribed drugs, which necessitate contact with a doctor, which thus gives the opportunity for professional help, these other methods need no such contacts.

The fact that hanging and poisoning by vehicle exhaust showed such large increases, whereas other methods showed much smaller increases, again indicates the complexity of factors affecting suicide. If some factor(s) - for example, unemployment - is responsible for the increase why have two methods of suicide shown such large increases and others little or no change? Clearly the independence of trends in suicide shown by Farmer over 100 years in England and Wales $^{3}$ also applies in Scotland. Farmer suggested that the independence could result if different sets of factors influenced suicide by the different methods. Alternatively, there may be a set of factors influencing predisposition to suicide (of which unemployment may be one) and other factors that influence the choice of method. Whatever the explanations the increasing trend in suicide rates is a growing public health problem.

The cardiovascular epidemiology unit is funded by the Scottish Home and Health Department.

\section{References}

1 Adelstein A, Mardon C. Suicides 1961-74. Population Trends 1975;2:13-8.

2 Kreitman N. The coal gas story: United Kingdom suicide rates, 1960-71. British foumal of Preventive and Social Medicine 1976;30:86-93.

3 Farmer RDT. Suicide by different methods. Postgrad Med f 1979;55:775-9.

4 Kreitman N, Platt S. Suicide, unemployment, and domestic gas detoxification in Britain. f Epidemiol Community Health 1984;38:1-6.

5 McClure GMG. Trends in suicide rate for England and Wales 1975-80. Br $\mathcal{F}$ Psychiatry 1984;144:119-26.

6 Bulusu L, Alderson M. Suicides 1950-82. Population Trends 1984;35:11-7.

7 Jones DIR. Self-poisoning with drugs: the past 20 years in Sheffield. Br Med $\mathcal{J}$ 1977; ;:28-9.

8 Registrar General Scotland. Annual report 1979. Edinburgh: HMSO, 1981.

9 Platt S. Unemployment and suicidal behaviour: a review of the literature. Soc Sci Med 1984;19: 93-115.

10 Smith R. "I couldn't stand it any more": suicide and unemployment. Br Med f 1985;291: 1563-6.

11 Kreitman N. Suicide in Scotland in comparison with England and Wales. Br $\mathcal{A}$ Psychiaty 1972;120:83-7.

12 Ross $\mathrm{O}$, Kreitman N. A further investigation of differences in the suicide rates of England and Wales and Scotland. Br $\mathcal{H}$ Psychiatry 1975;127:575-82.

13 Duffy JC, Plant MA. Scotland's liquor licensing changes: an assessment. BrMed f 1986;292:36-9.

14 Johns MW. Self-poisoning with barbiturates in England and Wales during 1959-74. Br Med 7 1977;i:1128-30.

15 Proudfoot AT, Vale JA. Acute poisoning: an update. Prescribers' fournal 1986;26:78-88. 16 Brewer C, Farmer R. Self-poisoning in 1984: a prediction that didn't come true. Br Med J
1985;290:391.

(Accepted 7 Julv 1987) 